\title{
Model of Use of Network Learning Systems in Sports and Scouting Courses
}

\author{
$1^{\text {st Khairul Usman }}{ }^{1}, 2^{\text {nd }}$ Wesly Silalahi ${ }^{2}, 3^{\text {rd }}$ Demmu Karo - Karo $^{3}$, \\ Winara $^{4}$ \\ \{khairulusman@unimed.ac.id ${ }^{1}$,wesly@unimed.ac.id ${ }^{2}$,demmukarokaro@g \\ mail.com³ ${ }^{3}$ winara@unimed.ac.id $\left.{ }^{4}\right\}$ \\ Universitas Negeri Medan \\ Faculty of Education Science, Departement Elementary Teacher Education 1,2,3,4 \\ Jalan Willem Iskandar, Sumatera Utara, Indonesia
}

\begin{abstract}
The purpose of this study was to produce a model of using online learning media in the Sport and Scouting Course of the Elementary School Teacher Education Study Program at the State University of Medan. The development of the concept of learning through online learning in courses can create a technology-sensitive culture, both lectures are oriented towards physical and theoretical skills competencies. The method that will be used is the research and development (R\&D) method which is analytical which includes design, production, and evaluation. The study of development procedures used is the Richey and Klein level 4 method, namely carrying out research and development steps by designing products. The data obtained were then analyzed through the Forum Group Discussion (FGD). The results of the study obtained that the effectiveness of the product was $93 \%$ with a very good category. The conclusion of the research is that the product can be used as a rule model for the development of online lectures in the Universitas Negeri Medan.
\end{abstract}

Keywords: Model, network learning systems, course.

\section{Introduction}

The use of technology is needed especially in the lecture process as the initial stage of character building and training to use technology in a sustainable manner. The effectiveness of giving lectures needs to be carried out as a new transformation, namely towards the modern era. Ali dkk 2006 in [1] revealed that traditional learning is characterized by a meeting between educators and students in the teaching and learning process. This method faces many obstacles when dealing with the limitations of the place and time of implementation, as it relates to the increasing number of students and student and learner activities in the global era, so it is necessary for students to be given learning experiences with various sources and learning media. Such a learning paradigm has begun to shift from face-toface learning directly to webbased courses such as video conferencing and e-learning.

The development of lecture media that will be developed will be a reference for online lectures. Online learning essentially has ease of use, especially in education that can be accessed anywhere via a smartphone or cellphone. Online or online learning will facilitate students to be able to learn independently and increase knowledge with unlimited time and 
familiarize students to take advantage of currently developing technology in a good direction according to learning needs.

Based on the above, it can be concluded that the development of technological innovation in the educational process is generally very much needed by educators in improving the quality of education, so that new findings in the field of education are highly expected considering that there are not many technological innovation developments at this time. The need for technology and its development is needed in improving and achieving the competencies that must be achieved by students.

Sistem Pembelajaran Dalam Jaringan (SIPDA) Universitas Negeri Medan merupakan media berbasis online yang digunakan sebagai akses komunikasi dan interaksi secara jaringan dalam melakukan perkuliahan. Sistem SIPDA dikembangkan oleh Universitas Negeri Medan (Unimed) secara mandiri berbasis moodle dan merupakan perbaharuan dari SIPOEL (System Portal Elektronik Learning) yang sebelumnya digunakan dalam pembelajaran online.

Medan State University (Unimed) online learning can be accessed through the website http://sipda.unimed.ac.id and can be accessed according to their respective faculties, namely for the Faculty of Education it is https://elearningfip.unimed.ac.id/ . The use of Sipda is strictly required by all Study Programs and Courses as a digital footprint of the implementation of lectures based on the industrial revolution 4.0, and the accreditation system as stated in the IAPT 3.0 (University Accreditation Instrument) and IAPS 4.0 (Study Program Accreditation Instruments) guidelines. The current accreditation system since 2020 refers to 9 standard criteria based on a network system. Another thing that becomes urgent regarding the use of Sipda is that the online learning system is one of the assessment criteria for improving and maintaining accreditation that has entered the superior category so that it can be evaluated without special review on the extension process stipulated in the Regulation of the Minister of Education and Culture of the Republic of Indonesia. [2].

Another development related to the use of SIPDA is as a lecture requirement in the Corona Virus Disease-19 pandemic situation or known as Covid-19, making the learning atmosphere carried out from home and lecturers carrying out their duties also from home. The policy was issued directly by the Ministry of Education and Culture (Kemendikbud) of the Republic of Indonesia and the State University of Medan to disable on-campus activities during the Covid-19 period and divert learning online.

The application of a mass online learning system to all Lecturers and Students at the State University of Medan turned out to be a lot of problems, including there are still many lecturers who have not used SIPDA as a teaching medium, but many lecturers prioritize the use of Google Classroom and Schoolgy in inputting lecture materials and materials. This then makes SIPDA not function properly, thus it is very necessary to make efforts to actualize the use of SIPDA in every course.

The development of information related to the use of SIPDA, especially at the Unimed Faculty of Education (FIP), was conveyed through the Deputy Dean I for Academic Affairs that the data inputted by the University stated that FIP was the lowest use of SIPDA at the University level of all existing faculties. Other data was obtained through the monitoring of the Faculty IT Team that until March 4, 2021, SIPDA users at FIP Unimed were only 8 lecturers out of all 104 lecturers. Based on this, it can be concluded that minimal use needs to be taken seriously as an effort to optimize online learning through SIPDA online media which was developed independently. This was then carried out with special assistance for SIPDA FIP elearning on March 9, 2021 at the Faculty of Education [3].

Adjustment of courses to the use of SIPDA is also a study that needs to be developed, namely, theory-based courses have an easier design than practice-based courses. Practicebased 
courses, namely Sports and Scouting in the PGSD Study Program, which are basically courses with full physical activity. If in normal situations, these lectures are always carried out in the field or not in the classroom, this is based on the competence in the subject, namely the formation of skills in carrying out physical or physical activities in the elementary school environment, so that each material is based on practice or learning motion. The basic competence of this course then becomes an important note that the actualization of lecture materials is transformed into SIPDA online learning without reducing the competency substance that must be achieved.

Sustainability of handling and efforts to increase the use of SIPDA as a medium for online lectures, it is very necessary for an actual development model in SIPDA-based lectures, especially in the Sport and Scouting subject of the Unimed Elementary School Teacher Education Study Program (PGSD). This design development can then be used as a rule model for optimizing the application of SIPDA in each subject in the Unimed FIP environment.

\section{Method}

The research design related to the actualization model of the use of SIPDA in the Sport and Scouting subject of the Unimed PGSD Study Program is to use the research and development (R\&D) method. Research or $\mathrm{RnD}$ is development research that serves to validate and develop products according to research needs [4]. The design used to formulate a material model specifically for the use of online lecture media.

The research procedure is carried out by explaining that the focus of design and development research is analysis which includes design, production, and evaluation. The study of the Richey and Klein method development procedure used is level 4, namely carrying out research and development steps by designing a product, design validation, design division, product manufacture, limited trial, product revision 1, main trial, product revision 2, operational field trials, product revision 3 , and finally dissemination and implementation.

\section{Resulth and Discussion}

The product development assessment is found in the indicators for evaluating the appearance of online learning, the carrying capacity of the material in online learning, and the effectiveness of the operation of online learning. The assessment process is carried out by respondents being able to fill in the instrument with a Likert scale, namely filling in the column score 5 has a very decent meaning, a score of 4 is feasible, a score of 3 is quite feasible, a score of 2 is less feasible, and a score of 1 is very less feasible. The assessment category can be seen based on the level of product significance, namely:

Table 1. Rating Category

\begin{tabular}{|c|c|c|}
\hline No & Category & Yield Range \\
\hline 1. & Very good & $90-100$ \\
\hline 2. & Well & $80-89$ \\
\hline 3. & Enough & $70-79$ \\
\hline 4. & Kurang Baik & $60-69$ \\
\hline
\end{tabular}




\begin{tabular}{|l|l|l|}
\hline 5. & Very Not Good & $<60$ \\
\hline
\end{tabular}

The limited product test assessment was carried out in 2 (two) groups with a total of 60 people, the main product test was carried out with 4 (four) groups with a total of 120 people, and the operational product test was carried out with 6 (six) groups with a total of 180 people.

The results of the assessment of the operational product test obtained an average score in group 1 with a total of 30 respondents, which achieved an assessment of $93 \%$ in the Very Good category. The assessment in group 2 with 30 respondents received an average rating of $93 \%$ in the Very Good category. The assessment in group 3 with 30 respondents received an average rating of $92 \%$ in the Very Good category. The assessment in group 4 with 30 respondents received an average rating of $93 \%$ in the Very Good category. The assessment in group 5 with 30 respondents received an average rating of $94 \%$ in the Very Good category. The assessment in group 6 with 30 respondents received an average rating of $92 \%$ in the Very Good category.

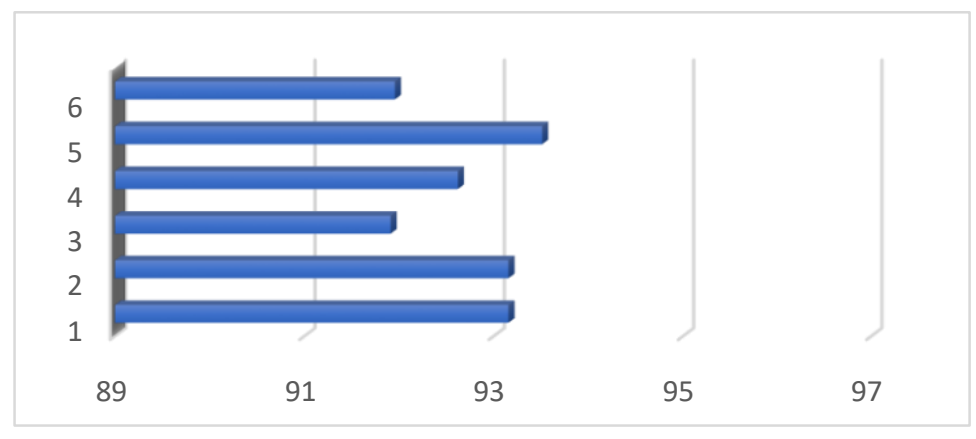

Fig. 1. Operational trial

The results of the product assessment analysis showed that the SIPDA development product for the Elementary School Sports and Scouting course was very good in presenting SIPAD that was attractive to users when they were going to do lectures or study companions from home. The result of the next analysis is that the product is very good in strengthening the elements of the Indonesian Qualifications Framework (KKNI) curriculum in the form of assignments and systematic composition of materials and the development of learning media that form high order thinking skills (Hots) reasoning. The result of the last analysis is on the aspect of effectiveness assessment, the product shows that the content of the material is very complete and in accordance with the Learning Outcomes of Competency Content (CPMK) lectures.

Product Design in the SIPDA Sport and Scouting course is then supported by supporting media, namely audio-visual based which has a role to facilitate students in mastering the concept of material and being able to lead to the aspect of creation and creation which in this case is known as the High Order Thinking Skill (HOTS) concept. The media supporting the material at SIPDA is the development of a design concept that is able to provide a stimulus for a well-established understanding, especially in online learning situations. 


\section{Conclusion}

The development of product design on the learning system in the Sport and Scouting course network has a feasibility element of $93 \%$ in the very good category. The very good category assessment is the embodiment of the preparatory design which includes the determination of the syllabus, Semester Lesson Plans (RPS), Assignment Concepts, and Determination of Materials at each meeting. Assessment support is also available at the implementation stage, namely by implementing and implementing lecture materials that have been prepared at the preparation stage. The implementation of the material is determined according to the lecture schedule which can be designed with attendance at each meeting.

Media in the learning system in the audio-visual-based Sports and Scouting course network has a role to facilitate students in mastering material concepts and being able to lead to aspects of creation and creation which in this case is known as the High Order Thinking Skill (HOTS) concept. The media that supports the material in this online learning system is the development of a design concept that is able to provide a stimulus for a well-established understanding, especially in online learning situations.

\section{References}

[1] Asyhar R. Kreatif Mengembangkan Media Pembelajaran. Jakarta: Referensi Jakarta; 2012.

[2] Mendikbud. Akreditasi Program Studi dan Perguruan Tinggi. Indonesia; 2020.

[3] Yusnadi. Surat Tugas. Indonesia; 2021.

[4] Sugiyono. Metode Penelitian \& Pengembangan Research and Development. Bandung: Alfabeta; 2017. 